\title{
THE SCHOOL OF AHL AL-SUNNAH WA AL-JAMA $\Varangle A H$ AND THE ATTACHMENT OF INDONESIAN MUSLIMS TO ITS DOCTRINES
}

\author{
Fauzan Saleh \\ STAIN Kediri, Indonesia
}

\begin{abstract}
The doctrine of Abl al-Sunnab wa al-Jama ath has been exploited by two major Muslim organizations in Indonesia, NU and Muhammadiyah, as the theological basis in determining their religious identity and rituals. Although these organizations claim that all Muslims should adhere to the doctrines of Abl al-Sunnah, they have never clearly defined that term. This paper discusses in detail the meaning of the term followed by an examination of the ways in which those two Muslim organizations attach themselves to this doctrine. This paper argues that, although the NU links itself to this doctrine, it is still necessary to critically examine to what extent its members apply the doctrines of Abl al-Sunnah in their daily life. Muhammadiyah, on the other hand, is not obsessed with the claim of being faithful to the doctrines of Abl al-Sunnah, although its constitution mentions that they advocate theological creeds which are evidently in line with the precepts of Abl al-Sunnah.
\end{abstract}

Keywords: Abl al-Sunnah wa al-Jama جrh, madhhab, NU, Muhammadiyah.

\section{Introduction}

For Indonesian Muslims, the term Abl al-Sunnah wa al-Jama $>b^{1}{ }^{1}$ has been used as a prototype of their religious attachment since the earliest

\footnotetext{
1 There is no standard spelling for this term in the Indonesian language. It can be either Ablussunnab Wal-Jama'ah (Dhofier), Ablus Sunnah wal Jama'ah (Mughni), Ablussunnah WalJama'ah (Ali), Ablus-Sunnah wal-Jama'ah (Aziz), or Ablus-Sunnab wal Jama'ah (Wahid). For NU, the term is usually abbreviated as ASWAJA. I will use the term Abl al-Sunnah wa al-Jama $a b$ throughout this paper.
} 
history of Islam in Indonesia. Almost all religious affiliations in Indonesian Islam are connected to the teachings of this school. The Nahdlatul Ulama' or NU, for instance, explicitly mentions in its institutional constitution that its followers have adopted this doctrine with an additional advocacy to struggle for the sake of Islam in accordance with one of the four Islamic legal schools, the Hanafite, Malikite, Shafi'ite, and Hanbalite. ${ }^{2}$ The earliest constitution of this organization (1930) stated that NU was established with the aim of upholding the teachings of the four madhhabs and to undertake all possible endeavors for the advantages of Islam. The constitution also insisted that it was necessary to examine all books that would be used for religious instructions to assure that they were entirely in agreement with the teachings of the Abl al-Sunnah wa al-Jama $>$ ab, and were not the books of heretics. ${ }^{3}$ The Muhammadiyah, on the other hand, although less explicitly, also adopts this doctrine as one of its Tarjib's decisions on the principles of belief which are to be based on the precepts of $a b l$ al-hodq wa al-sunnah. ${ }^{4}$

Although these organizations claim that all valid Islamic groups in Indonesia should adhere to the doctrines of Abl al-Sunnah, they never

2 The emphasis on this issue was reinforced at the 26 th $\mathrm{NU}$ General Conference (Muktamar) in Semarang (1979), in which it was proclaimed that NU aims to uphold the Sharith of Islam according to the school of Abl al-Sunnah wa al-Jama 2 th, that is to follow the four Islamic legal schools $(\mathrm{H}\{$ nafi $>\mathrm{Ma}$ i $>\mathrm{Sha} \mathrm{i}>$ and $\mathrm{H}\{$ nbalip and to implement the teachings of Abl al-Sunnab wa al-Jama $a b$ in the daily life of the community. See Choirul Anam, Pertumbuban dan Perkembangan Nabdlatul Ulama' (Sala: Jatayu, 1985), p. 135.

${ }^{3}$ M. Ali Haidar, Nabdatul Ulma' dan Islam di Indonesia: Pendekatan Fikih dalam Politik (Jakarta: Gramedia, 1994), p. 69, quoting from Statuten Perkoempoelan Nabdlatoel Oelama, Rechts persoon, 6 February 1930, no. lx, article 2.

4 Pimpinan Pusat Muhammadiyah, Himpunan Putusan Tarjih (Yogyakarta: PP Muhammadiyah, n.d.), p. 20. Unlike NU, Muhammadiyah prefers the use of abl al-h sqq wa alsunnab to Abl al-Sunnah wa al-Jama $>$ ab. The term used by Muhammadiyah is indeed in

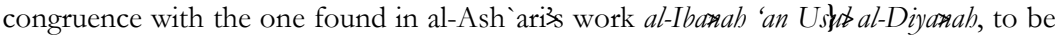
differentiated from its opposite, abl al-riyag wa al-bida', that is the people of transgression and innovation (in religious belief and observance). See Abuج्al-H\{san al-

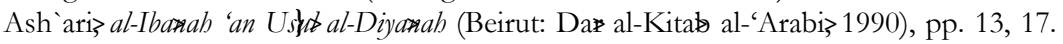
Tarjis a departmental institution in the Muhammadiyah organization consisting of some scholars and experts, especially in Islamic jurisprudence, whose duty is to consider some legal opinions on religious matters. This, and other departments, has been established in order to translate the objectives of Muhammadiyah into reality. 
clearly defined the term Abl al-Sunnah wa al-Jama $>b$ or what an affinity to this school of thought actually entails. This paper will discuss in detail the description of the term Abl al-Sunnab wa al-Jama $>b$ followed by an examination of the ways in which religious groups in Indonesia, both traditionalist and modernist camps, attach themselves to this school of thought. More specifically, although the NU deliberately links itself to this doctrine, it is still significant to examine to which extent the members of this traditional religious association apply the doctrines of Abl al-Sunnab in their daily life, since in general they tend to incorporate some practices that have no valid foundation in the textual resources, essentially those originating from the local customs which are largely of the influence of Hindu, Buddhist or animistic traditions. They do so, more or less, in order to support the idea of tolerance and flexibility, especially with regard to their claim of representing the majority of Indonesian Islam.

\section{The Abl al-Sunnab; A General Overview}

Generally speaking, the use of the term Abl al-Sunnab wa al-Jama $\geq x$ indicates the Islamic school of thought followed by the majority of the Muslim ummah, "to distinguish themselves from other Islamic sects whose views, they maintain, constitute bida' (sg. bid ah, "innovations"), departures from what the community at large holds." 5 A.J. Wensink writes that Abl al-Sunnab wa al-Jama $>$ ab or "the people of the Sunnah and the Community" are those who refrain from deviating from orthodox dogma and practice; this expression is used specifically in opposition to the Shi $\mathrm{ah}_{\mathrm{h}}{ }^{6}$ But historically, it has been closely related to the development of political Islam since its early formative period. Like other general issues discussed in Islamic theology, this term is primarily related to the problem of the imamate, an issue which marks the first instance of a clear distinction in Islamic identity. At this time, some Muslims began to label themselves "Sunni"in contrast to the Shi $\gg>$

The most serious issue dividing the Sunni from the Shi $\ngtr \ngtr$ this very question of the imamate, concerning the controversy over who was eligible to be elected as a caliph of the Prophet. For the Sunnis, the accession of the first four caliphs represents the true order of

\footnotetext{
5 Michael E. Marmura, "Sunni Islam," in The Oxford Encyclopedia of the Modern Islamic World, vol. 4, p. 140.

${ }^{6}$ A.J. Wensinck, “Sunnah,” in Encyclopedia of Islam, first edition, vol. 7, p. 555.
} 
excellence. The problem actually stems from a discussion of the relative merits of 'Uthmaßand 'Ali and the question of whether or not it was appropriate for 'Uthma to hold the caliphate prior to 'Ali $\gg \mathrm{Abu}>$ $\mathrm{H}\{\mathrm{ni}$ h, in his treatise al-Fiqh al-Akbar, states: "We leave the question of "Uthma and 'Ali oo Go," which implies that he inclined to accept the ideas expressed by the Murji'ites. More significantly, this shows his opposition to Shi $\ngtr$ point of view which gave a special place to 'Ali> ahead of the other three caliphs. Abu $¥$ \{nifh reportedly explained further: "We do not dissociate from any of the companions of the Messenger of God, nor do we associate with one rather than another." This idea is generally supported by the Sunnis acceptance of the position of the first four caliphs after the Prophet, in contrast to that of the Shi $>$ who believed that Ali was the only rightful successor to Muhammad. All Shi $\$$ \&, except the Zaydis, considered the first three caliphs usurpers of the caliphates. ${ }^{7}$

Although Sunni Islam is usually claimed to be related to the Ash arite school of theology, ${ }^{8}$ there is evidence for the use of this term prior to Ash ari $\nsucc$ Usually it refers to those who sought direct reference to the text of the Qur'a and the Sunnah for solutions to problems that arose; when they could not find any reference in either, they kept silent, because they did not want to transgress or go beyond the divine sources. They were better known as abl al-hddit, representing the companions of the Prophet and their followers. They were also known as al-salaf (predecessor, ancestry), to be differentiated from the abl alra'y or the people of "reasoned opinion" who tended to rely on intellectual exercises in solving problems through the use of qiyas $>$ or analogical reasoning. Their dispute initially began with the problem of the attributes of God. The salaf, or abl al-hdditant maintained that God possesses eternal attributes of knowledge, power, life, will, hearing, seeing and speaking, among others, and they did not differentiate between the attributes of essence (sifat al-dhat and the attributes of activities (sifat firlizab). Rather they noted that these attributes were mentioned in the Shari anh, and therefore should be simply described as "testified attributes" (sifat khabarizab). They were also unwilling to

\footnotetext{
7 See W. Montgomery Watt, The Formative Period of Islamic Thought (Edinburgh: Edinburgh University Press, 1973), pp. 265-266.

${ }^{8}$ See Anam, Pertumbuban dan Perkembangan NU, pp. 139-140.
} 
interpret those attributes. Ma b. Anas, for instance, when asked for the meaning of the Qur'anic verse which describes God as sitting on a throne (al-'arsh), simply replied: "The sitting is known, but the modality of His sitting is unknown, and the belief in it is obligatory, and questioning on it is a heresy." This idea was supported by other jurists,

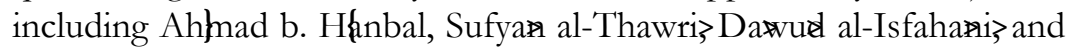
their followers. ${ }^{9}$

In addition to the above explanation, the use of the term $\mathrm{Abl}$ alSunnah wa' a-Jama $>$ mb is also based on some traditions of the Prophet which state that the Muslim ummah would split into seventy-three groups after the age of the Prophet, all of which would go to hell, except one. That single group, according to the Prophet, consists of those who maintain (the sunnah of) the Prophet and of his companions. The last phrase "those who maintain the sunnah of the Prophet and of his companions" becomes very important because it represents the standard measure by which Muslims evaluate the possibility of attaining salvation. This statement is further clarified in another $\mathrm{H}\{$ dit stating that the one group who will gain salvation is aljama meaning the community (of believers). The term "community," in turn, also signifies the majority, as indicated by another saying of the Prophet that God will never allow the ummah of Muhłmmad to agree on an error (dala above the community. Whoever isolates him or herself from the community will be left alone in hell. An additional comment was given in a $\mathrm{H}\{$ dit narrated by Ibn Majh saying that whenever a dispute takes place, the believer should associate with the majority who maintained

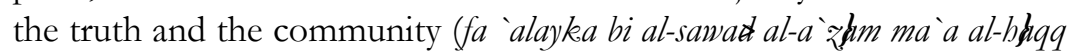
wa al-jama $>b) .{ }^{10}$

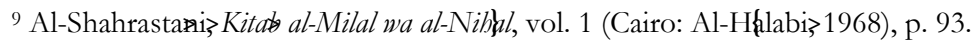

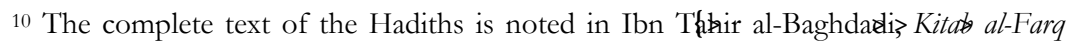
bayn al-Firaq wa Bayaæal-Firqah al-Naßjah minha Egypt: al-Ma a 1910), pp. 4-5, with an explanation of those seventy-three groups concerned in the following pages. The same $\mathrm{H}\{$ diths are also quoted by some Indonesian writers for the sake of advocating the concept of Sunnism, especially among the NU writers. See, for instance, H. Amin Ali, Ablussunnah wal Jama'ah dan Unsur-unsur Pokok Ajarannya (Semarang: Wicaksana, 1980); and Rs. Abd Aziz, Konsepsi Ablussunnah wal-Jamaah dalam Bidang Aqidah dan Syari'ah (Pekalongan: Bahagia, 1990).
} 
In addition to the above exposition, Ibn T\{alir al-Baghdał $>$ summarizes the general features of the followers of Abl al-Sunnah wa alJama $>h$ as those who believe in the unity of God, hold the dogmas of promise and threat (al-wa'd wa al-wai $\rightarrow$, reward and retribution. They tread the path of the Sifatiyah who accept the doctrine that God has eternal attributes, declare themselves free from anthropomorphism as well as divesting God of His attributes and steer clear of the Qadarite views and of Mu'tazilism. They affirm the possibility of seeing God with human eyes without falling into the error of tashbis (anthropomorphism). They acknowledge the resurrection from the grave, and recognize the truth of the pool (al-hawd), the bridge (al-siza $\rightleftharpoons$, the intercession (al-shafa polytheism. They recognize the imamate of Abußakr, 'Umar, 'Uthmaæ and 'Ali, and they venerate highly the pious ancestry (al-salaf al-s d the ummah. They realize the necessity of congregational prayers on Fridays under the leadership of the imams. They also realize the necessity of extracting the precepts of law from the Qur'aæ, the Sunnah and the consensus of opinion (ijma Pamong the Companions. They urge obedience to the Sultans in whatever does not involve sinfulness. Also included in this group are those who possess a comprehensive knowledge of the $\mathrm{H}\{$ dit and the Sunnah of the Prophet and can discern the sound from the fabricated ones; and the Sufi ascetics who indulge in learning and abstain from pleasure, resign to fate and are content with the obtainable. Their way of life is to entrust themselves to God, submitting to His command, feeling satisfied with whatever has been bestowed upon them and abstaining from rebelling against Him. Finally, included to this group are those of the general population among whom the practices of the orthodox prevail while they do not attach themselves to any innovation or heresy, but only to the doctrines approved by the orthodox in relation to the problems of justice and unity, reward and punishment. ${ }^{11}$

With reference to the above explanation, it seems clear that $\mathrm{Abl}$ alSunnab wa al-Jama $\gg h$ was a term commonly used to legitimize a theological point of view. It was also inferred that other schools of

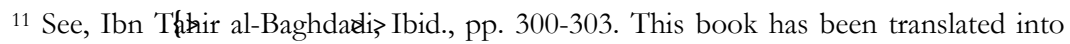
English by Abraham S. Halkin, under the title of Moslem Schisms and Sects (al-Fark Bain al-Firak) Being the History of the Various Philosophic Systems Developed in Islam (Tel Aviv: Palestine Publishing Co., 1935). For this English translation, see Part II, pp. 159-163.
} 
thought which did not agree with this has allegedly strayed away from the true path of God and the Sunnah of the Prophet. It can be derived from the above explanation too that the use of the term Sunnah indicates that the followers of this school should adopt the Sunnab or the traditions established by the Prophet and his companions, usually called the salaf or predecessors (of the Muslim community). Moreover, their traditions are considered to have been representing pure Islam, free from any form of heresy. As they also used the term $a b l a l-h$ dqq, they claimed that their religious doctrines are the only truth which should be accepted and observed by all Muslims. They also claimed that they consistently maintain the truth, as they called themselves abl al-istiqamah. Finally, the use of the term jama or community, emphasizes their historical consciousness on the basis of the support of the majority of Muslim people. In other words, they should maintain the historical continuity of the ummah in order to avoid disintegration. Consequently, this group accepted the caliphate of alMa'muß, although the latter was too much inclined to support the Shi $\$$ and suppress those who opposed Mu'tazilite doctrines, like Imam Ahrod b. Hanbal, ${ }^{12}$ who was celebrated as the leading figure of the salaf school.

\section{Claims of Attachment to the Doctrines of Abl al-Sunnab}

The attachment of Indonesian Muslims to the doctrines of $\mathrm{Abl}$ alSunnab can be scrutinized through several Islamic religious groups prevailing in this country. But for the sake of simplification, I will focus on the NU and Muhammadiyah groups as the major representatives of Indonesian Islam. While the first represents the traditionalist point of view, the second represents the modernist Islam.

For the NU members, as has been indicated above, the doctrines of Abl al-Sunnab wa al-Jama $a b$ are very central. They claim those doctrines to be the main core of their religious identity. The establishment of $\mathrm{NU}$ was primarily meant to uphold the doctrines of this school of thought among Indonesian Muslims. Choirul Anam, in the work cited above, also emphasizes this idea. He states that among the basic considerations that led to the founding of this organization in

\footnotetext{
12 Syafiq A. Mughni, "Ahlus Sunnah wal Jama'ah dan Posisi Muhammadiyah" in Din Syamsuddin (ed.), Mubammadiyah Kini \& Esok (Jakarta: Pustaka Panjimas, 1990), pp. 261-261.
} 
1926 was a desire to respond the demands of traditionalist Muslims to propagate the doctrines of Abl al-Sunnah wa al-Jama $>b$ in Indonesia. ${ }^{13}$ It is not surprising that NU members are more concerned with this issue than those belonging to other groups. They constantly stress their affiliation with the doctrines of this school, and tend to claim that it is only their group that has an authentic attachment to it. For them, the true Islam is that of the Abl al-Sunnab wa al-Jama $>$ although they do retain their own interpretation of this claim.

Anam begins his discussion with an intense look at the early development of Islam in Indonesia. He suggests that the spread of Islam in Indonesia (especially in Java) was mainly promoted by the Nine Saints, better known as Wali Songo, who applied several different approaches to their propagation (da'wah) of Islam. Each wali should have taken a particular approach due to their varied perceptions of the nature of the Indonesian people at that time. More notably, Anam examines two different approaches: one held by Raden Rahmat or Sunan Ampel of Surabaya and by Sunan Giri of Gresik, and the other held by Sunan Kalijaga. According to the first two walis; Islam should be introduced to the indigenous people of Java directly in its pure and pristine form, free from every element of heresy and syncretism; and all indigenous customs deviating from the spirit of Islam should not be tolerated. All forms of obscurantisms, superstitions, idolatries and heresies must be suppressed immediately. But, for Sunan Kalijaga, who once lived in the agrarian region of Central Java, and was culturally close to the Javanese Court, considered the above approach held by Sunan Ampel and Sunan Giri as inappropriate to be applied in an area where the population was heavily overwhelmed by Hindu-Buddhist traditions for many centuries.

The approach in preaching Islam held by both Sunan Ampel and Sunan Giri could be suitable only for people living in coastal regions, who were by nature more open to different currents of ideas and culture, due to their straightforward access to wider communication with a large variety of people coming from many different countries by the way of sea. Kalijaga maintained that the propagation of Islam could not be undertaken abruptly against local culture. Rather, it should be carried out through persuasion by providing a broad tolerance of local customs. Kalijaga went even further in trying to accommodate or

${ }^{13}$ See Anam, Pertumbuban dan Perkembangan NU, pp. 35 ff. 
revive local culture. He argued that through this broad tolerance he could invite more converts peacefully; once they had accepted Islam, he would lead them towards its pure teachings gradually, although it might take a long time. However, he reduced some of the severe challenges presented by mass conversion by avoiding a contrast that was too drastic. ${ }^{14}$

Anam suggests that Sunan Kalijaga's approach is more appropriate for the NU, and is frequently applied by the ulama $>$ who teach in Pesantren, or traditional Islamic boarding schools. In their propagation of Islam, the ulama $>$ associated with the NU usually become more tolerant of certain deviations from orthodox Islam, a result of the influence of indigenous customs. They have even argued that local cultures could be used as a vehicle for spreading Islam more extensively. This tendency is clearly manifested in several events related to local customs and adapted to religious ceremonies, such as marriage, circumcision, the celebration of the birthday of the Prophet Muhammad, and certain ceremonies devoted to a deceased persons (tablilan, slametan) on the third, seventh, hundredth, and thousandth anniversary of the day of his or her death. These ceremonies are still popularly practiced among the NU members. ${ }^{15}$ 14 A more extensive discussion on this issue can be found in Agus Sunyoto, Sejarah
Perjuangan Sunan Ampel: Taktike dan Strategi Dakwah Islam di Jawa Abad 14-15 (Surabaya:
LPLI-Sunan Ampel, n.d.), especially pp. 79-93. See also Solichin Salam, Wali Sanga
dalam Perspektif Sejarah (Jakarta: Kuning Mas, 1989), pp. 38-39. Each of the walis was
ascribed the designation Sunan, derived from the word Susubunan, a royal title in the
Javanese court, especially in Surakarta. See Agus Sunyoto, ibid, p. 80. The nine saints
are Sunan Ampel, Sunan Bonang, Sunan Giri, Sunan Drajat, Sunan Gunung Jati,
Sunan Kalijaga, Sunan Kudus, Malik Ibrahim, and Sunan Muria. There were a few
other names usually attached to them, such as Syekh Siti Jenar and Raden Fatah. See
M.T. Arifin, Gagasan Pembaharuan Muhammadiyah (Jakarta: Pustaka Jaya, 1987), pp. 44-
46.

15 Agus Sunyoto also mentions that some of the traditions maintained by the NU members originated from Shi'ite traditions, initially introduced by Syekh Siti Jenar in the $15^{\text {th }}$ century. Siti Jenar came from Persia, and was considered one of the earliest propagators of Islam in Java, contemporaneous of Sunan Kalijaga. Like Kalijaga, Siti Jenar, whose original name was 'Abdul Jalil, tended to incorporate local customs into Islamic practices, and promoted some Shi'ite elements to the Javanese people. His propagation, although supported by Kalijaga, was considered a deviation from the mainstream Islam promoted by other walis, especially concerning his mystical concept of wablat al-wuju or pantheism. This, among other things, was regarded as one of the legal reasons for condemning him with a death sentence. See, ibid., pp. 91-93. 
This tendency was severely criticized by the modernist Muslim movement in Indonesia, especially by the Muhammadiyah and Persatuan Islam or PERSIS, ${ }^{16}$ the two leading organizations promoting Islamic reform in Indonesia. Even prior to the establishment of these organizations in 1912 and 1923 respectively, the idea of reform had influenced some Indonesian leaders who went to Mecca for pilgrimage, due to easier transportation facilitated by the Dutch Administration. As a result, the idea of reform grew and spread until it was finally embodied in new movements like those of the Muhammadiyah, al-Irshad and PERSIS. They encouraged Muslims to revive their understanding of religion through direct reference to the principal sources of Islamic doctrines, the Qur'aæand Hadił, and to avoid all elements of heresy, superstition and idolatry. Anam does not specifically mention that the establishment of NU was in fact a reactionary measure against the reform movement launched by the Muhammadiyah and PERSIS, but rather indicates that NU was established in response to the general Islamic reform occurring in the Islamic world, particularly that promoted by the Wahha $\$$ movement in the Arabian Peninsula. ${ }^{17}$

But Achmad Farichin Chumaidy, writing his M.A. thesis in 1976 on the Jam'iyah Nahdlatul Ulama', emphasizes that in addition to the development of Wahhabi movement in Hijaz, the establishment of NU actually could not be separated from the conflicts and disputes between the orthodox and reformist groups which had been taking place in Indonesia for a considerable period of time. The orthodox group realized that their dispute with the reformists would never be solved and felt that the latter's attack undermining the madhbab teaching was becoming more effective and fierce. The reformist groups, in order to strive toward their ideal and unify their followers, had established organizations, such as Muhammadiyah, Persatuan Islam and al-Irshad. Stimulated by what had been done by their opponents, the orthodox group intended to establish their own organization as a forum for discussing religious matters and a channel for maintaining and spreading madhbab teachings among the

\footnotetext{
16 With regard to the PERSIS criticism toward NU concerning these practices, see Howard M. Federspiel, Persatuan Islam: Islamic Reform in Twentieth Century Indonesia (Ithaca, New York: Modern Indonesian Project, Cornell University, 1970), pp. 69-83.

17 Anam, Pertumbuban dan Perkembangan NU, p. 49.
} 
Indonesian community. Chumaidy supports his idea with a statement made by K.H. Masykur, one of the NU's leading figures, when the latter justified the NU's withdrawal from the Masyumi, in 1952: "The organization of the Nahdlatul Ulama' was created in reaction to the emergence of the movement whose desire was to abolish the madhhab school in Indonesia, as well as in Hifaßwhere Ibn Sa u wrested the power."18

Nevertheless, the Indonesian ulama $>$ were worried that the advancement of the Wahharimovement under the patronage of the Sa u dynasty would cause unfavorable changes in terms of performing the religious rites in the Hifaz. They heard that the Wahha ; > through its purification campaign, had abolished the madhhab system, forbidden people to visit the tombs of Muslim heroes (including that of the Prophet) and prohibited Muslims from conducting pilgrimage rituals based on madhhab principles, among other things. They were even more threatened by a rumour that the Hifa $\rightarrow$ land was only secure for those who supported the Wahhał> movement, and that the lives of those who continued to subscribe to the madhhab system would be endangered there.

All these issues aroused a great anxiety among the traditional ulama $>$ in Indonesia who considered the adoption of the madhhab system essential for the performance of religious duties. Accordingly, they convened to create a committee whose members could be sent as delegates to King Sa u $\$$ in the Hifas, demanding his guarantee of the freedom to adopt madhhab doctrines. They also requested that traditional religious practices, such as the erection of tombs on graves and the reading of certain prayers (dala al-khayrat), should be respected. The committee, called the Hifa $\rightarrow$ Committee, was set up in January 1926. Once the formation of the committee was completed, however, the question arose as to whom the committee would be responsible. Finally, it was agreed that the committee would be responsible to the body of 'ulama -who associated themselves with the newly founded movement, named Nabdlatul Ulama', or the resurgence of the 'ulama $>$ The foundation of the Hifa $>$ Committee was celebrated

\footnotetext{
18 Achmad Farichin Chumaidy, “The Jam'iyah Nahdlatul Ulama: Its Rise and Early Development (1926-1945).” M.A. Thesis, McGill University, 1976, pp. 35, 41. The direct quotation is based on Verslag Lengkap Muktamar NU ke 19 di Palembang (Jakarta: Pengurus Besar NU Bagian Dakwah, 1952), p. 1.
} 
at the same time as the establishment of the Nahdlatul Ulama' or NU. ${ }^{19}$

After all, the establishment of NU was meant to consolidate the Indonesian 'ulama 7 who were concerned with the demand to maintain the madhhab institution as a legitimate way to understand as well as practice religious doctrines. K.H. Hasyim Asy'ari, for instance, the founding father and the great leader (al-ra'isal-akbar) of NU, vigorously emphasized the necessity of following a madhhab. In his celebrated speech known as Qanun Asasi Nabdlatul Ulama', he reminded Muslims in Indonesia that there would be great benefit to adopting the four madhhabs and serious evil in abandoning them. He argued that in order to be able to observe religious doctrines correctly, Muslims must follow their predecessors. This theory was exemplified by the second generation (tarim of the early Muslims, who took their religion from their predecessors, and likewise the generations following them, known as tal-talitis This is because, according to Asy'ari, the intellect has approved following a madhhab as a successful way of practicing Islam, adding that religion is not knowledgeable without transmission and inference. Yet, transmission is invalid without connecting one generation directly to the preceding generation; as for inference, it is necessary to be cognizant of the schools of the past, and not to deviate from their decisions, which would destroy the agreements reached by the “ulama $>$ n religious matters.

In addition, Asy'ari emphasized that the four madhhabs were only legitimate representatives of the majority of the ummah. Asy'ari supports this conclusion by referring to the saying of the Prophet that Muslims should follow the great majority (al-sawa $a l-a^{\prime}\left\{q^{2} m\right.$ ). Since other righteous madhhabs already disappeared due to a lack of support from their adherents, Asy'ari pointed out, following the majority of the ummah as ordained by the Prophet means subscribing to one of the four legitimate madhhabs of the Sunni school of law: Hanafi>Ma $>$ i> Sha $>>$ and $\mathrm{H}\{$ nnbali $>$ Asy'ari also emphasized the necessity of taqli the unquestioning acceptance and adoption of concepts or doctrines laid down by the leaders of the madhhabs. ${ }^{20}$

\footnotetext{
19 Anam, Pertumbuban dan Perkembangan NU, pp. 49-55.

${ }^{20}$ K.H. Hasyim Asy'ari, Qanun Asasi Nahdlatul Ulama' (Kudus: Menara, 1969), pp. 5260.
} 
It seems clear that NU's attachment to the doctrines of $A b l$ alSunnah wa al-Jama $>h$ was decided by its founders as the principal tenets which members of this religious organization were required to adopt obediently. Their concept of being a devout Muslim means that one who sticks closely to the principles laid down by the madhhab leaders in

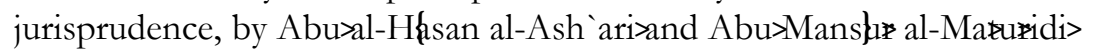

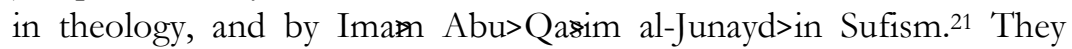
maintain that following one of the four madhhabs is legitimate, and must be fortified, since they believe that the religious principles formulated by the madhhab leaders are based on the Qur'a and the Sunnah of the Prophet. The ulama $>$ of NU also maintain that certain religious practices like tablilan, tawassul, slametan or giving charity for the interests of the deceased are based on religious principles, although they cannot find authoritative $\mathrm{H}\{$ dit mentioning any of these traditions. They simply insist that these traditions must be based on the practices of the companions of the Prophet which were accepted and ordained by the Prophet. ${ }^{22}$

\section{Muhammadiyah's Attitude}

With regard to Muhammadiyah's attitude toward the concept of Abl al-Sunnah wa al-Jama $>h$, it can be said that this religious association, except in its Tarjih decision mentioned earlier, does not claim a special attachment to the doctrines of Abl al-Sunnah. The Muhammadiyah movement, since its establishment in 1912, has always been most concerned with promoting the necessity of reform or tajdi in Indonesia Islam. However, when the organization was accused by other Muslim groups in the country of being beyond the bound of the Abl al-Sunnab wa al-Jama $>$ ah, one of its prominent leaders, Djarnawi Hadikusuma, vehemently denied the accusation. In response, he wrote a small treatise entitled Muhammadiyah Ablu Sunnab wal Djama'ah? in which he defends the Muhammadiyah's position against that

21 Zamakhsyari Dhofier, Tradisi Pesantren: Studi tentang Pandangan Hidup Kyabi Jakarta: LP3ES, 1985), p. 149.

22 Aziz, Konsepsi Ablussunnah wal-Jama'ah, p. 82. Tablil refers to the recitation of the phrase la $>$ ila illa $\gg$ lla , with other prayer formulas recited for multiple purposes. On certain occasions, the reward of practicing this prayer is devoted to the spirit of a deceased person, as held on slametan. For the meaning of these specific terms, see Howard M. Federspiel, A Dictionary of Indonesian Islam (Athens, Ohio: Center for International Studies, 1995). 
accusation. This small treatise was originally meant to be supplementary material for the Muhammadiyah proselytizers (muballigh), designed to allow them to respond correctly to questions as to whether or not the Muhammadiyah belonged to the Abl al-Sunnah wa al-Jama $>b$ or followed the madhbab. 23

But the most significant attitude taken by Muhammadiyah on this issue is that it does not explicitly adopt a particular madhhab of jurisprudence. Muhammadiyah claims that it would be more appropriate, recognizing that it is quite possible for modern Muslims to learn and adopt several currents of thought at the same time. It is even more beneficial, since, by freeing itself from attachment to a particular madhhab, the followers of Muhammadiyah can anticipate the development of current tendencies of Islamic thought which appear to grow more pluralistic. Hence, they have freedom to broaden their minds without being psychologically constrained by the fear of violating the doctrines of a certain madhbab. In contrast with NU, Muhammadiyah is not obsessed with the claim of being encompassed within the sphere of Abl al-Sunnah, although its constitution mentions that they advocate theological creeds which are evidently in line with the precepts of Abl al-Sunnah. Accordingly, Muhammadiyah is fairly able to claim itself of being a "non-sectarian" movement. ${ }^{24}$

By applying direct reference to the Qur'a and the Sunnah for concepts of religious matters, Muhammadiyah has called itself an Islamic reform movement since the early decades of the twentieth

23 Djarnawi Hadikusuma, Mubammadijah Ablu Sunnab wal Djama'ab? (Yogyakarta: Siaran, n.d.), p. 2. Later, this treatise was reprinted together with another work of his, Bid'ah-Khurafat. The two works are now republished as a single book, Ablus Sunnah wal Jama'ah, Bid'ah, Khurafat (Yogyakarta: Persatuan, 1996).

${ }^{24}$ Mughni, “Ahlus Sunnah wal Jama'ah,” p. 274. In spite of its original heated debate concerning the necessity of following a particular madbhab obediently, Muslims today tend to be more open to the diversity of ideas in perceiving and observing their religious traditions. This is due, among other things, to the possibility of practicing talfip, which means that one is justifiably allowed to follow the judgment of any recognized school of thought. Previously, such a practice was frowned upon as an arbitrary and opportunistic legal practice. However, the reformists, figureheaded by Muhłmmad 'Abduh at the turn of the nineteenth century, advocated it as a means of overcoming legal problems in one school by turning to more appropriate answers provided by another. See, Abdulkader Tayob, Islam: A Short Introduction Signs, Symbols and Values (Oxford: Oneworld, 1999), pp. 144-145. Advocating reform movement of Islam, the Muhammadiyah tends to be closer to this idea. 
century. For Muhammadiyah, this reform movement is designed to restore the teachings of Islam in their pure and original form as manifested in the Qur'a and the Sunnah, free from any element of heresy and superstition, as true reflections of the principal characteristics of Islam. Muhammadiyah intends to use this reform to reconstruct religious life in the form of a pristine Islam. In this way, Muhammadiyah becomes the vindicator of Islamic precepts and all forms of ritual practices against deviant and heretical tendencies. Reform or tajdi of this type is accordingly called "purification."

On the other hand, as Islam encompasses universal values, the tajdidof Muhammadiyah also refers to the implementation of Islamic teachings in accordance with the demands of the developments of the modern age. This is specifically related to the non-ritual aspects of Islamic teachings which deal with social and humanitarian issues not strictly regulated by Islam but are relinquished to human reasoning, except for general guidelines. Tajdi $>_{\text {of }}$ this type is called "renewal." With regards to the first form of tajdit, Muhammadiyah realizes that there are always some tendencies among Muslims themselves to deviate from the original teachings of Islam. This does not mean that Islamic teachings are defective, however, since Muslims believe that Islam as religion is complete and perfect. Nevertheless, deviation might occur in implementing the true doctrines of Islam, due to some influences originating from local culture or the Muslim's lack of understanding in terms of their true belief. ${ }^{25}$ On the other hand, Muhammadiyah believes that Islam as a religion is suitable for modern society.

Islam, in other words, does not contradict modernism and is applicable to modern life. This is because Islam has laid down its principal teachings in accordance with the development of mankind. ${ }^{26}$ More clearly, Abdul Mu'ti Ali, who wrote his M.A. thesis on Muhammadiyah in 1957, notes that the main factors which led to the establishment of this religious movement were the impurity of religious life, the inefficiency of religious education, the activities of Christian activities, and the indifferent and even anti-religious attitude

25 Achmad Jainuri, "Landasan Teologis Gerakan Pembaruan Islam," in Ulumul Qur'an, vol. 6, no. 3 (1995), pp. 41-42.

${ }^{26}$ Ibid., p. 45. See also Umar Hasyim, Muhammadiyah Jalan Lurus dalam Tajdid Dakwah, Kaderisasi dan Pendidikan: Kritik dan Terapinya (Surabaya: Bina Ilmu, 1990), pp. 187-188. 
of the intelligentsia, which were very common among Indonesian people. These are the main areas where Muhammadiyah endeavoured to introduce reforms. ${ }^{27}$

Muhammadiyah asserts in its constitution that it is an Islamic movement designed to propagate Islam through ordaining goodness and forbidding evil (al-amr bi al-ma'rufma al-naby 'an al-munkar) based on the precepts of Islam as manifested in the Qur'a and the Sunnah. Accordingly, the main objectives of the establishment of this movement are the purification of Indonesian Islam from corrupting influences and practices, the reformulation of Islamic doctrines in light of modern thought, the reformation of Muslim education and the defence of Islam against external influences and attacks. ${ }^{28}$ After all, this organization is aimed at fortifying and upholding the religion of Islam for the sake of achieving a noble, righteous and prosperous community under the favour of God. ${ }^{29}$ It seems clear that although Muhammadiyah does not explicitly express its attachment to the school of $\mathrm{Abl}$ alSunnah wa al-Jama $\geq h$, the principles laid down by this organization are not contradictory to its doctrines as they are initially defined. More specifically, Muhammadiyah is, to a particular extent, similar to orthodox Islam, which is also called $A b l$ al- $H a d$ dit, in its ritual practices, ethics, as well as in its theological point of view. ${ }^{30}$

\section{Conclusion}

Indonesian Muslims' attachment to the doctrines of Abl al-Sunnah wa al-Jama $>b$ has been explicitly claimed by the NU, as manifested in the objectives of the establishment this organization, as well as in several works of its writers. Some NU writers have tried to reformulate the principal doctrines of Abl al-Sunnah, although these attempts tend

\footnotetext{
27 Abdu'l-Mu'ti Ali, "The Muhammadiyah Movement: A Bibliographical Introduction" (M.A. Thesis, McGill University, 1957), pp. 21-22.

28 Ibid., p. 50.

29 Pimpinan Pusat Muhammadiyah, Pedoman Bermubammadiyah (Yogyakarta: PP Muhammadiyah, Badan Pendidikan Kader, 1990), p. 21.

30 Howard M. Federspiel, "The Muhammadiyah: A Study of an Orthodox Islamic Movement in Indonesia." Indonesia, no. 10 (October 1970), p. 58. This article has been translated into Indonesian language, and is incorporated in Syamsuddin's editional work, Mubammadiyah Kini \& Esok, pp. 81-121, with the title "Studi tentang Muhammadiyah sebagai Gerakan Ortodoks."
} 
to be somewhat cursory and less academically researched. ${ }^{31}$ Nevertheless, these works represent the general features of the NU today and its strict adherence to the doctrines of Abl al-Sunnab wa alJama $>$ th.

Their attachment to these doctrines is another factor which distinguishes the NU members from those of the other Islamic organizations developed in Indonesia. It is evident that the NU members adhere to their own understanding of the concept of $\mathrm{Abl}$ alSunnah wa al-Jama $>b$ and entirely implement the teachings of Islam according to that understanding. So far, there has been no problem in this matter, except that the advocates of this organization tend to monopolize the claim as the only legitimate adherents of the teachings of the Abl al-Sunnab wa al-Jama $>$ hh, and thus exclude the other Muslim groups, even accusing of being outside the pale of Islam. This claim can be seen, for instance, in the following quotation:

The teachings of $A b l$ al-Sunnab wa al-Jama $>b$ in Indonesia will flourish more rapidly, because we realize that among the programs of the NU is primarily to defend and fortify the teachings of Abl al-Sunnah wa al-Jama $x h$. While the majority of the Indonesian Muslims are members of the $\mathrm{NU}$, it involuntarily implies that the Islamic doctrines adopted by the Indonesian Muslims are those belonging to the Abl al-Sunnah wa al-Jama $>b^{32}$

\footnotetext{
${ }^{31}$ See, for instance, H. Amin Ali and Rs. Abd. Aziz in the works mentioned above, especially in pp. 77-132 for Ali; and pp. 87-115 for Aziz. Abdurrahman Wahid also tried to write on in this issue, though it is very general, and does not directly deal with the details of the doctrines of Ahl al-Sunnah. See his "Kerangka Pengembangan Doktrin Ahlus-sunnah wal Jama'ah (ASWAJA)" as compiled in his Muslim di Tengab Pergumulan (Jakarta: Leppenas, 1981), pp. 34-45. A more comprehensive and profound discussion of this issue can be seen in Dhofier's work Tradisi Pesantren, cited above, in Chapter VI, pp. 148-170. However, this discussion is only a part of his extensive examination of the role of the kyai in the pesantren.
}

32 Aziz, Konsepsi Ablussunnah wal-Jamaah, p. 86. In the 1950s there was a heated debate between the NU and PERSIS concerning this issue. Since the NU accused the MASYUMI (which the PERSIS was politically associated with and became its important constituent) of being outside the pale of Islam. The PERSIS, in return, argued that the epithet of "Abl al-Sunnab wa al-Jama $>b$ " is not a guarantee for somebody to enter paradise. The name is only a name, without any special value. The PERSIS went even further by stating that the term Abl al-Sunnab wa al-Jama $>b$ should not be applied to any group that adheres to a madhhab, since the legal formulations of the madhhabs were the products of human reason and did not have the sanction of the 
However, the advocates of NU consistently claim to have implemented Islamic doctrines based on the Sunnah of the Prophet and that of his companions. Adopting the Sunnah of the companions is considered very instrumental for them, because it is through the Sunnah of the companions that they suppose to justifiably perform some specific ritual practices not adopted by other Muslim groups in Indonesia. These specific practices include performing taramis prayers with twenty raka'ats (instead of eight), reciting qunusin the morning prayer (subb)\}, making two for Friday prayers (rather than one),

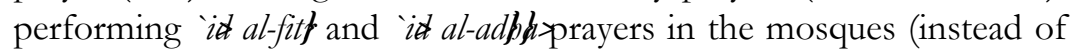
in the courtyards) and practicing some slametan, tablilan and other popular traditions unknown in the original teachings of Islam. ${ }^{33}$ These are some of the ritual and traditional practices which generally differentiate the NU from Muhammadiyah and other religious reform movements in Indonesia.

Muhammadiyah, maintaining its reform ideology and religious purification, is reluctant to consider these popular practices as valid, since they are not clearly ascribed to the real teachings of the Prophet. The members of this reform movement prefer not to speculate on the matter of ritual doctrines by assuming that certain traditions, although they have no valid reference to the Prophet, are favourable merely because the majority of Indonesian Muslims have performed them in their daily practices. Muhammadiyah, in contrast, emphasizes rigid practices in ritual matters, accepting only the proven traditions obviously taught by the Prophet.

Although the NU followers exclusively claim their attachment to the doctrines of Abl al-Sunnah, this does not necessarily mean that other Muslim groups in Indonesia do not perform their religious duties correctly, and vice versa. This, in turn, requires further examination to verify as to which one of them is actually closer to the real belief of Islam, or at least as designed by the Abl al-Sunnah wa al-Jama $x$. The claim made by $\mathrm{NU}$ members that their religious practices to be the sole authentic expression of Abl al-Sunnab wa al-Jama $a b$ dogma has served

Qur'a and the Sunnah. They asserted that the PERSIS, and not the NU, which truly belongs to the Abl al-Sunnah wa al-Jama $>$ ah, because the PERSIS always works against the perpetuation of heresy (bid'ab) in religious matters, while conforming to correct religious doctrines and behaviors. See Federspiel, Persatuan Islam, pp. 162-163.

33 Anam, Pertumbuban dan Perkembangan NU, p. 139. 
the organization well in its recruitment of the largest number of followers among Indonesian Muslims. Yet, at the same time, their adherence to the Abl al-Sunnab is also used to legitimize ritual practices that cannot be authoritatively ascribed to the Prophet. For the sake of maintaining their popularity, they extend their tolerance to traditions that were unknown in the pristine Islam. The real difficulty, however, is the fact that the NU's bold claim to the Abl al-Sunnab tends to exclude other Muslim groups from the pale of Sunnism, and thus effectively delegitimizing them.

Nevertheless, despite some differences in traditions and practices, both the Muhammadiyah and NU remain outstanding representatives of Indonesian Islam. Each of them maintains that it follows only the religion of Allah, which is, as noted by one of the NU leading figures, nothing other than His revelation, His doctrine, as well as His law or the Shari ${ }^{34}$ As the greatest Muslim organizations in Indonesia, both the NU and the Muhammadiyah are generally known as representing the traditionalist and modernist camps, respectively. Once, it is evidently true, they were perceived as symbolizing the doctrinal conflict prevailing among Indonesian Muslims. However, although the strife could sometimes grow serious, in subsequent years the advocates of these two factions came to understand that in reality their differences were without depth, not even touching upon the more fundamental principles, and did not jeopardize their respective reputation as devout Muslims.

It is also impossible to see any member of these organizations accusing a person belonging to a different school of thought of being infidel, something that might have happened in the 1950s. The late Nurcholish Madjid, one of the most prominent Indonesian Muslim scholars, suggests that both the Muhammadiyah and NU actually have exemplified the two wings of a single eagle. It may in fact likewise have been historically willed by God that they should coexist within the Indonesian Islam. Madjid argues that according to the Qur'anic decree God has created all existing beings in pairs, consisting of two contradictory parts. They should, therefore, not exaggerate their differences but rather try to come closer together and cooperate in the

\footnotetext{
34 Masdar Farid Mas'udi, "Menuju Keberagaman yang Populistik: Reorientasi Pemikiran Keagamaan Nahdhatul Ulama - Muhammadiyah," in Yunahar Ilyas et el. (eds.), Muhammadiyah dan NU: Reorientasi Wawasan Keislaman (Yogyakarta: Kerjasama LPPI UMY, LKPSM NU dan PP Al-Muhsin, 1993), p. 187.
} 
attempt to actualize the ideals of Islam for the well being of all people in their homeland. ${ }^{35}$

According to Madjid, Indonesian Muslims should learn much from history how Muslims in the past responded to challenges they encountered in every era and locality. Among the early Muslim scholars who successfully resolved the problems they were encountering were Ibn Si and Ibn Rushd in philosophy, al-Junayd and al-Bist $\rightarrow$ in Sufism, and the four madhbab leaders in jurisprudence. But in spite of discrepancies in their approaches and the results they had achieved, there was always a "common denominator," that unified their spirits in the school of jama which later on became the foundation of the school of Abl al-Sunnah wa al-Jama $x h$, the very term being the subject matter of this current discussion. Madjid agrees with the fact that Indonesian Sunnites are the followers of Abu $\gg$ l$\mathrm{H}\{\mathrm{s} a \mathrm{n}$ al-Ash a four madhhabs in jurisprudence, and of al-Junayd and al-Bistłmi $>$ in Sufism.

Madjid emphasizes that Indonesian Muslims should avoid reiterating the disputations over controversial issues that had been inherited from the medieval era. It would be better for Indonesian Muslims to direct their energy toward establishing a new Weltanschaung (worldview) in the theological, cosmological and anthropological realms. He hopes that by establishing this new Weltanschaung Muslims will be able to discover the specific paradigms that will allow them to respond better to current challenges. Muslims should be able to benefit from the achievements of medieval scholars who were deeply rooted in Islamic traditions so that they can broaden their religious horizons.

In making this assessment, Madjid insists that it is not necessary for Muslims to begin everything in their religious matters from zero. To support his idea he frequently refers to a saying popularly circulated

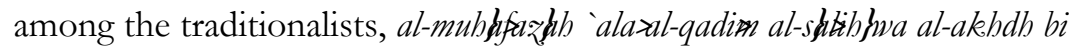

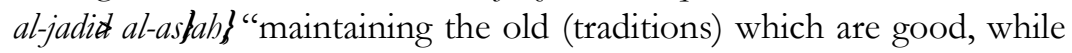

\footnotetext{
35 Nurcholish Madjid, "Reorientasi Wawasan Pemikiran Keislaman: Usaha Mencari Kemungkinan Bentuk Peran Tepat Umat Islam Indonesia di Abad XXI," in ibid., pp. 193-194. Madjid refers to the Qur'anic verse, "Glory to Allah, Who created in pairs all things that the earth produces, as well as their own (human) kind and (other) things of which they have no knowledge" (36:36), and "And of everything We have created pairs: That you may receive instruction," (51:49) to support his arguments.
} 
accepting the new (matters) which are better." 36 He seems thereby to be implicitly criticizing the position of the Muhammadiyah. Madjid maintains that due to its unyielding emphasis on the necessity of purification by solely returning to the Qur'aß and $\mathrm{H}\{\mathrm{dith}$, and its efforts to eradicate all religious innovations (bid'ah), the Muhammadiyah has unduly undermined certain Islamic traditional legacies. Although the Muhammadiyah has developed deeper insights concerning current world issues, Madjid argues, it nevertheless lacks a traditional basis. Accordingly, Madjid suggests that it would be better if Indonesian Muslims could combine the merits possessed by both the modernists and the traditionalists, ${ }^{37}$ for the advancement of Muslims' role for the betterment of the people's well being in this country.]

\section{Bibliography}

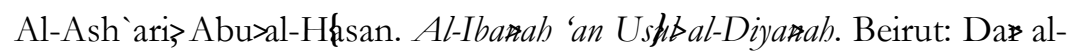
Kitaßal-`Arabi, $>1990$.

Ali, Abdul Mu'ti. “The Muhammadiyah Movement: A Bibliographical Introduction.” MA Thesis, McGill University, 1957.

Ali, H. Amin. Ablussunnah wal Jama'ah dan Unsur-unsur Pokok Ajarannya. Semarang: Wicaksana, 1980.

Anam, Choirul. Pertumbuban dan Perkembangan Nabdlatul Ulama'. Sala: Jatayu, 1985.

Arfin, M.T. Gagasan Pembaruan Mubammadiyah. Jakarta: Pustaka Jaya, 1987.

Asy'ari, K.H. Hasyim. Qanun Asasi Nahdlatul Ulama'. Kudus: Menara, 1969.

Aziz, Rs. Abd. Konsepsi Ablussunnah wal-Jamaah dalam Bidang Aqidah dan Syariah. Pekalongan: Bahagia, 1990.

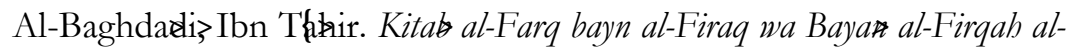

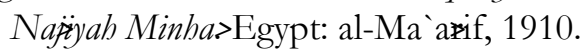

\footnotetext{
36 See his article, "Aktualisasi Ajaran Ahlussunnah Wal Jama'ah," in Muntaha Azhari and Abdul Mun'im Saleh (eds.), Islam Indonesia: Menatap Masa Depan (Jakarta: Perhimpunan Pengembangan Pesantren dan Masyarakat, 1989), pp. 62-63.

${ }^{37}$ Nurcholish Madjid, "Menegakkan Faham Ahlus-Sunnah 'Baru'," in Haidar Bagir (ed.), Satu Islam, Sebuah Dilema (Bandung: Mizan, 1986), pp. 32-34.
} 
Moslem Schisms and Sects (al-Fark Bain al-Firak) Being the History of the Various Philosophical Systems Developed in Islam, translated by Abraham S. Halkin. Tel-Aviv: Palestine Publishing Co., 1935.

Chumaidy, Achmad Farichin. “The Jam'iyah Nahdlatul Ulama: Its Rise and Early Development (1926-1945)." MA Thesis, McGill University, 1976.

Dhofier, Zamakhsyari. Tradisi Pesantren: Studi tentang Pandangan Hidup Kyahi. Jakarta: LP3ES, 1985.

Federspiel, Howard M. Persatuan Islam: Islamic Reform in Twentieth Century Indonesia. Ithaca, New York: Modern Indonesia Project, Cornell University, 1970.

-. "The Muhammadiyah: A Study of an Orthodox Islamic Movement in Indonesia." Indonesia, no. 10 (October 1970), pp. 57-79.

--------. A Dictionary of Indonesian Islam. Athens, Ohio: Center for International Studies, 1995.

Hadikusuma, Djarnawi. Ablus Sunnah wal Jama'ah, Bid'ah, Khurafat. Yogyakarta: Persatuan, 1996.

Haidar, M. Ali. Nabdatul Ulma' dan Islam di Indonesia: Pendekatan Fikih dalam Politik Jakarta: Gramedia, 1994

Hasyim, Umar. Muhammadiyah Jalan Lurus dalam Tajdi Dakwah, Kaderisasi dan Pendidikan: Kritik dan Terapinya. Surabaya: Bina Ilmu, 1990.

Jainuri, Achmad. "Landasan Teologis Gerakan Pembaruan Islam." Ulumul Qur'an, vol. 6, no. 3 (1995), pp. 34-48.

Madjid, Nurcholish. "Reorientasi Wawasan Pemikiran Keislaman: Usaha Mencari Kemungkinan Bentuk Peran Tepat Umat Islam Indonesia di Abad XXI," in Yunahar Ilyas et el. (eds.), Mubammadiyah dan NU: Reorientasi Wawasan Keislaman. Yogyakarta: Kerjasama LPPI UMY, LKPSM NU dan PP AlMuhsin, 1993. -. "Aktualisasi Ajaran Ahlussunnah Wal Jama'ah ," in Muntaha Azhari and Abdul Mun'im Saleh (eds.), Islam Indonesia: Menatap Masa Depan. Jakarta: Perhimpunan Pengembangan Pesantren dan Masyarakat, 1989. 
-. 'Menegakkan Faham Ahlus-Sunnah 'Baru'," in Haidar Bagir (ed.), Satu Islam, Sebuab Dilema. Bandung: Mizan, 1986.

Marmura, Michael E. "Sunni Islam." The Oxford Encyclopedia of the Modern Islamic World, vol. 6, pp. 139-141.

Mas'udi, Masdar Farid. "Menuju Keberagaman yang Populistik: Reorientasi Pemikiran Keagamaan Nahdhatul Ulama Muhammadiyah," in Yunahar Ilyas et el. (eds.), Mubammadiyah dan NU: Reorientasi Wawasan Keislaman. Yogyakarta: Kerjasama LPPI UMY, LKPSM NU dan PP Al-Muhsin, 1993.

Mughni, Syafiq A. "Ahlus Sunnah wal Jama'ah dan Posisi Teologi Muhammadiyah," in Din Syamsuddin (ed.), Mubammadiyah Kini \& Esok. Jakarta: Pustaka Panjimas, 1990, pp. 259-279.

Muhammadiyah, Pimpinan Pusat. Himpunan Putusan Tarjih. Yogyakarta: PP. Muhammadiayh, n.d.

-. Pedoman Bermuhammadiyah. Yogyakarta: PP. Muhammadiyah Badan Pendidikan Kader, 1990.

Salam, Solichin. Wali Sanga dalam Perspectif Sejarah. Jakarta: Kuning Mas, 1989.

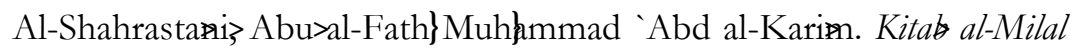
wa al-Nihd?. Cairo: al-H\{labi>1968.

Sunyoto, Agus. Sejarah Perjuangan Sunan Ampel: Taktik dan Strategi Dakwah Islam di Jawa Abad 14-15. Surabaya: LPLI Sunan Ampel, n.d.

Tayob, Abdulkader. Islam: A Short Introduction Signs, Symbols and Values. Oxford: Oneworld, 1999.

Wahid, Abdurrahman. Muslim di Tengah Pergumulan. Jakarta: LEPPENAS, 1981.

Watt, W. Montgomery. The Formative Period of Islamic Thought. Edinburgh: Edinburgh University Press, 1973.

Wensinck, A.J. "Sunna." Encyclopedia of Islam, first edition, vol. 7, pp. 555-557. 